УДК 93/99:37(=161.1)(571.1/5)

DOI: $10.32340 / 2414-9101-2021-2-18-23$

С. И. Бондаренко, кандидат исторических наук, доцент Алтайский государственный аграрный университет (Барнаул, Россия) bonsvet@bk.ru

\title{
ДУХОВНО-ЭКОЛОГИЧЕСКАЯ КУЛЬТУРА РУССКОГО КРЕСТЬЯНСКОГО МИРА ЗАПАДНОЙ СИБИРИ
}

Аннотация. Проанализирован духовно-экологический, трудовой опыт исторического русского крестьянского мира Западной Сибири (Россия). Рассмотрена роль крестьянской общины, семьи в формировании духовно-экологических традиций сельского сообщества. Охарактеризована актуальность и востребованность традиционных крестьянских трудовых и экологических практик в исторически сложные, экстремальные периоды исторического развития России. Автор характеризует актуальность базовых духовно-экологических ценностных крестьянских установок в современных условиях.

Ключевье слова: духовно-экологическая культура, крестьянство, традиционные знания, труд, семья, община, природа, адаптащия, природосберегающие приёмыл.

Крестьянство на протяжения всего своего существования теснейшим образом было связано с окружающим природным ландшафтом. Каждодневное взаимодействие с природой преображало и духовный мир крестьянства. Так исследовательница сибирского крестьянства М. М. Громыко, характеризуя духовную культуру русских хлебопашцев XVIII-XIX вв. отмечала духовную связь крестьянина с окружающей природой его органичное включение в систему локальных природных условий $[1$, с. 10]. На практической значимости изучения взаимодействия крестьянства с природой акцентировал свое внимание исследователь В. М. Федоров: «Неумение видеть диалектику глобального и локального оборачивается просчетами в хозяйственной деятельности. Мы сами обедняем себя, не используя возможности, предоставленные нам природой» [2, с. 28]. Современные экологические проблемы делают актуальным изучение традиционных духовно-экологических практик крестьянства, с точки зрения их природообусловленности и природосберегающих приемов хозяйствования.

Крестьянство, являясь самым многочисленным слоем населения в России, накопило огромный объём эмпирических сельскохозяйственных и экологических знаний, успешно применяя его при освоении новых территорий. Еще В. О. Ключевский определял колонизацию как основной фактор развития России. Крестьянство же в колонизационном процессе играло ключевую роль. С XVII века Сибирь становится территорией крестьянского освоения. Несмотря на многочисленные трудности, Сибирь уже в XVII в. начала обходиться своим хлебом. Успешность освоения территории зависела от многих факторов, не последнюю роль в этом играли экологические знания крестьян, влияние природного ландшафта на хозяйственную деятельность и ее влияние на окружающую среду.

Основные сельскохозяйственные занятия определяли образ жизни крестьян, их мировоззрение и формировали особую духовно-экологическую культуру. Изучение природных явлений, наблюдения, являлись для крестьян жизненной необходимостью, так как различные природные катаклизмы засуха, заморозки, наводнения и т. д. могли в одночасье поставить крестьянскую семью на грань голода. Главным источником знания для крестьян являлось наблюдение. Так по данным Миненко Н. А. сибирские крестьяне имели представления о естественных причинах образования дождя, умели объяснить происхождение туманов, знали множество примет надвигающегося дождя, мороза, пурги и т.д., так же крестьяне умели делать долгосрочные прогнозы, Хлебопашцы различали виды морозов, их названия были приурочены к религиозным праздникам. По этим данным сибирские крестьяне определяли время сева [3]. 
По данным исследователей Алтая, в частности Н. М. Ядринцева сибирские крестьяне имели склонность к антропоморфизму. Исследователь отмечал склонность крестьян к одушевлению не только земли, но и животных, птиц, рек, гор и т. д. [4, с. 102]. Обращает на себя внимание способность крестьян видеть красоту мироздания, примеры этому мы можем видеть в крестьянском фольклоре. До сих пор мы встречаем такие описания, как «красное солнышко», «ясный месяц» и т. д. Об эмоциональной связи сельского мира с природой говорили многие исследователи Сибири. Так Г. Н. Потанин замечал, что не только экономическая выгода манила зверовщиков в тайгу, но и притягательная сила лесной жизни, наслаждение от пребывания в лоне природы. По приведенным исследователем воспоминаниям жен соболевщиков, «они видели своих мужей в слезах при наступлении времени соболиной охоты, и многие из них вспоминали об этом как о «прожитом счастье» $[5$, с. 155$]$.

Сибирские хлебопашцы активно изучали и растительный мир края. Им были знакомы лечебные свойства трав, места богатые ягодами, грибами, орехами и т. д. По данным Н. М. Ядринцева, крестьяне знали несколько десятков лекарственных трав, что стало основой формирования традиционной народной медицины. Крестьяне Сибири различали несколько сортов диких луков «слизун», «вшивик», «колба», чеснок [4, с. 70]. Сибирские крестьяне хорошо разбирались в грибах, знали повадки птиц и животных, замечали изменения в рыбных ресурсах края.

Основательно была изучена сибирскими крестьянами водная система края. Крестьяне имели достаточно хорошие знания о реках, озерах, притоках, времени вскрытия и замерзания рек, составе воды, замечали изменения водных артерий. Сибирские хлебопашцы благодаря своей наблюдательности открыли ряд целебных источников. Например, в 1848 г. в Бийском округе у устья реки Берели местным жителем был обнаружен теплый ключ, позже получивший название «Рахмановский», по фамилии нашедшего крестьянина. По данным Голубева П. А. в источнике крестьяне активно лечили язвы, пневмонии, ячмени и др. заболевания, в целом же горы Алтая изобиловали минеральными ключами, а в Барнаульском округе было большое количество озер с запасами различных солей (поваренной, глауберовой, бромистых, калийных и др.). В 1868 г. крестьянин Семен Казанцев открыл теплый целебный ключ в Ново-Белокурихе на реке Солоновка. Вода источника имела температуру $26^{\circ} \mathrm{C}$, зимой не замерзала, была прозрачная, мягкая на вкус. Позже стараниями известного исследователя Алтая С. И. Гуляева ключ приобрел благоустроенный вид [6, т. 4. c. 269].

В процессе земледельческого освоения сибирского региона крестьянство выработало наиболее рациональные приемы и способы обработки почв. Так, учитывая особенности климатических условий, крестьяне тщательно подходили к выбору земли под пашню. Крестьяне выбирали под посев порой худшую почву, но находящуюся в более благоприятных климатических условиях, более защищенную от ветров и иссушающей жары. Крестьянством Сибири были разработаны свои агротехнические приемы обработки целинной и залежной земли. В целом приемы и способы обработки почвы по данным исследователей были выработаны на основе многолетней практики и исходили из местных условий. На их основе решались основные проблемы земледелия Сибири сохранение влаги в почве и уничтожение сорной травы. Обработка паров способствовала более длительному сохранению земли в севообороте экстенсивного хозяйства, восстанавливать производительные силы и тем самым продлевать срок эксплуатации пашни.

Функция передачи хозяйственного и духовно-экологического опыта следующим поколениям в Сибири принадлежала главным образом общине и семье. Община в Западной Сибири заботилась о сохранении кормящего ландшафта. В работах Миненко Н. А. приведено множество примеров заботы крестьян об экологии. Так крестьяне д. Комаровой в 1772 г. подали коллективную жалобу в Бийскую земскую избу на своих соседей из д. Шубинской, за ловлю рыбы большим неводом. В 1810 г. была подана жалоба крестьянами села Гутова Кайлинской волости на колыванских мещан, обломавших множество веток при сборе ягод. В 1834 г. в Юдинской волости крестьяне добились запрета на ловлю рыбы в Чановских озерах для приезжих, так как те вырубали лес по берегам озер и портили сенокосы [3, с. 47] и т. д. В Сибири крестьяне очень бережно относились к кедровым рощам. Исследователи предполагают здесь и влияние государственной политики. 
Так в 1766 г. сибирским губернатором Д. Чичериным был издан указ, требовавший от крестьян не рубить деревья на дрова, а пользоваться уже подрубленными, и не обдирать с березы кору. В целом община сама строго контролировала лесные угодья исходя из своих хозяйственных соображений.

При отсутствии агрономов, специальных сельскохозяйственных школ функцию освоения и передачи сельскохозяйственного и промыслового опыта в Сибири наряду с общиной осуществляла семья. Во многих местностях Сибири были развиты так называемые «семейные» промыслы, что предполагало обязательное овладение детьми соответствующих навыков. Кроме овладения непосредственно трудовыми навыками крестьянская традиция предполагала знание подростками различных обрядов, примет, для успешного ведения хозяйства. Традиционно детей в крестьянской среде приобщали к труду с малолетства. Уже в детских колыбельных песнях звучали мотивы о недопустимости лени, об окружающем мире, о распределении обязанностей между членами семьи. По данным Зверева В. А. старших сестер в сибирских крестьянских семьях называли «няньками», иногда такой няньке могло быть 3-4 года [7, с. 116]. Так исследователь, ставя вопрос, было ли столь раннее привлечение детей к труду только объективной необходимостью, или это являлось специальным педагогическим приемом, обеспечивающим трудовое воспитание, приходит к выводу, что оба эти фактора были взаимосвязаны. В. А. Зверевым выделяется ряд педагогических приемов, которые применялись в сибирских семьях. Это опосредованность педагогического влияния, создание атмосферы радости, и нужности труда всех членов семьи. Не последнюю роль в создании особой трудовой атмосферы играли семейные сельскохозяйственные обряды. (Заметим, что создание атмосферы радости труда было позже заимствовано советскими руководителями, особенно в период руководства Н. С. Хрущева и отражено уже в советских трудовых обрядах). Своеобразным итогом трудового воспитания становилось приобщение крестьянских детей к хозяйственному опыту и знаниям родителей. Нельзя не отметить роль помочей в выработке и передаче производственных навыков, экологических знаний, трудовых традиций. Помочами в Сибири называли неоплачиваемый труд для быстрого окончания работы у отдельных крестьян.

Помимо общины и семьи существенную роль в формировании, сохранении и передачи трудовых, экологических традиций в Западной Сибири играла артель. Под крестьянской промысловой артелью следует понимать временное производственное объединение на определенных условиях для выполнения совместных работ. Артель создавалась тогда, когда силами одной семьи невозможно было заниматься определенным промыслом. Артель получила распространение в таких промыслах как охота, лесозаготовка, кедровый промысел и др. Основная целью промысловых артелей было - организовать трудовой процесс, выработать наиболее рациональные приемы промысловых операций, сплотить коллектив, создать благоприятную эмоциональную среду трудового процесса. Молодые люди могли получить знания, опыт старших поколений. При подборе артельщиков принимались во внимание не только трудовые навыки промысловика, но и этические (доброта, честность, уживчивость). По данным 3. П. Горьковской для формирования благоприятного климата иногда в артель приглашали рассказчиков, «посказателей». Непосредственно в промысле они не участвовали, но свою долю они получали за создание благоприятной трудовой атмосферы [8, с. 152]. Удачно подобранные с эмоциональной точки зрения артели, могли существовать длительное время. Различные формы передачи трудовых, экологических, духовных традиций, степень их функционирования определяли их ведущую роль в передаче традиций следующим поколениям.

Современники, изучающие хозяйственную деятельность сельского мира, подчеркивали консервативный характер аграрной культуры крестьянства, приверженность традициям. Это объяснялось значительной зависимостью от природного кормящего ландшафта. Зависимость хозяйственной деятельности от природы диктовала необходимость воспроизводить проверенный опыт предшествующих поколений. Отступление от хозяйственного и экологического опыта «предков» грозило катастрофой. Таким образом, крестьянский традиционализм, своеобразная «костность» были запрограммированы природным воздействием и служили гарантом благополучия сельского мира. 
Но это отнюдь не означало отсутствие места для инноваций и принятие нового хозяйственного опыта. Приспособленное к местным хозяйственно-экологическим условиям традиционное семейное хозяйство становилось платформой для таких инноваций.

Значительные изменения крестьянские хозяйства в Западной Сибири претерпели в годы столыпинских реформ. Относительно традиционного семейного хозяйства в Западной Сибири исследователи отмечали, что господство общинных порядков не было уж слишком отягчающим для крестьян. «Каждый хозяйничает так как ему нравится; всякий молодец на свой образец», - писал А. Третьяков о шадринских крестьянах $[9$, с. 50] При достаточном свободном земельном фонде, умении рачительно хозяйствовать, имея опыт артельных объединений, столыпинская реформа, делавшая акцент на развитии индивидуальных хозяйств, дала Сибири, несмотря на противоречивые итоги в целом, весьма значительные результаты.

В настоящее время историками Д. Б. Струковым и Т. К. Щегловой уже отвергается тезис о том, что П. А. Столыпин, разрушая общину, разрушал традиционные крестьянские устои. Историки говорят не столько о разрушении общины, сколько о возвращении ей исконного облика, существовавшего до крепостного права, а конкретно о восстановлении мирского (волостного самоуправления) при личном владении пахотным наделом отдельными крестьянскими хозяйствами. Предполагалось ликвидировать именно фискально-бюрократическую опеку, в целом не свойственную русской общинной организации $[10$, с. 89$]$. Д. Б. Струков также говорит о том, что столыпинская реформа укрепляла мелкую крестьянскую собственность при этом саморазрушалась именно деформированная крепостническая традиция, а вот «социальное ядро национального уклада - традиционная семья получала дополнительные стимулы» [11, с. 405-406].

Заметим, что Сибирь, в частности, явилась примером учета Столыпиным региональных особенностей в проведении аграрных преобразований. Здесь крестьянская община много сделала для приема переселенцев, организации землеустроительных работ. Определенная свобода хозяйствования, помноженная тяжелый труд, опирающийся на многовековые традиции, давала значительные экономические результаты.

Не забывались в годы реформы и экологические аспекты хозяйствования. В годы столыпинских реформ осваивались труднообрабатываемые южные районы тайги. Раскорчевка леса под пашню была затратной и трудоемким процессом, тем не менее, крестьяне заботились о сохранении природного ландшафта. При вырубке деревьев крестьяне часто оставляли пни на месте, хотя это доставляло определенные неудобства при обработке почвы. Дело было не только в трудозатратности, но и в том, что свежевыкорчеванный пень нарушал верхний почвенный слой, поэтому пень удаляли через несколько лет, когда корни несколько подгнивали. Это позволяло сохранить верхний почвенный слой. Забота о земле-кормилице оставалась важным фактором крестьянской духовно-экологической культуры. Но было очевидно, что без научного подхода дальнейшее рациональное природопользование невозможно. Переселенческое управление стало инициатором создания в Сибири опытных учреждений и организации научных учреждений.

Первая мировая война и последующие революции, реформы «сверху», преимущественно насильственного характера прервали естественную эволюцию развития сельского хозяйства как страны в целом, так и Сибири в частности и привели к изменению, традиционных форм и практик природопользования и крестьянского жизнеобеспечения. Однако как показала практика жизнеобеспечения в экстремальных условиях в годы Великой отечественной войны, традиции небыли забыты.

В годы войны крестьянство вновь вернулось к традициям коллективного труда - «труду вскладчину», «помочам». Сибирское крестьянство решало проблемы голода и холода, опираясь на традиционную культуру жизнеобеспечения. Поскольку в годы войны изменился половозрастной состав села, распределение трудовых семейных обязанностей также осуществлялось с опорой на традиции сельского мира. Раннее вовлечение детей в трудовые производственные отношения вновь стали нормой. Также в годы войны сельскому миру пришлось вернуться к промысловой деятельности. По данным Т. К. Щегловой сельский мир достаточно быстро адаптировался к сложным условиям войны благодаря тому, что имелись знания и навыки решения таких проблем с 
опорой на «кормящий ландшафт». Автор отмечает, что «у русского населения собирательство являлось частью трудовых традиций, начиная с освоения Сибири» [12, с. 198] Основой собирательства стал традиционный опыт, адаптированный к местным природно-климатическим условиям и дополненный заимствованными навыками у коренного населения. В целом промысловая деятельность в годы войны зависела от окружающего природного ландшафта. Во многом, благодаря традиционным трудовым, экологическим знаниям крестьянству удалось выжить в экстремальных условиях.

Осуществлявшаяся в советский период переориентация специфики хозяйств, их специализация без учета особенностей природного ландшафта и экологического опыта предков привела к многочисленным экологическим ошибкам.

В годы освоения сибирской целины практически не учитывалась специфика сухостепного земледелия, были механически перенесены методы отвальной обработки почвы из центральных районов страны. Вследствие чего эрозийные процессы почвы в 60-х годах и пыльные бури, нанесли заметный экологический ущерб природному ландшафту Сибири. Такая особенность традиционного крестьянского хозяйства как учет местной среды (микроклимат, рельеф, почвы и т. д.) сменялась на грубое покорение природы.

Очевидно, что решение экологических проблем, переход к устойчивому развитию сельских территорий возможен только при использовании новейших технологических достижений. Однако при этом все же необходимо учитывать опыт предшествующих поколений. Это опыт ценен, прежде всего, тем, что он учитывает природно-климатическую, географическую среду «кормящего» ландшафта. К огромному пласту эмпирических знаний, накопленных крестьянством, следует относиться как к значительному пласту культуры, которая является уникальным средством адаптации к окружающей среде. Так сохранённые многими поколениями крестьян навыки природопользования, механизмы адаптации к природной среде, способы выживания в экстремальных ситуациях помогли, например не только физически выжить в годы войны, но и обеспечить необходимой продукцией фронт, что в конечном итоге обеспечило победу. Безусловно, социально-экологический опыт был вписан в прошедшие уже технологические и социальные отношения, но при всех успехах современного уже информационного общества, жизнь людей теснейшим образом связана с природой, использовании ее ресурсов. Не секрет, что пандемийные времена, вновь актуализировали дачную и огородную жизнь людей. Использование здесь традиционных приемов, адаптированных к местным условиям, может оказаться весьма эффективным.

Большую практическую ценность представляют традиционные навыки эффективного использования микроландшафта и микроклимата местности, опыт рационального соотношения между земледелием и животноводством для каждого региона, биологические методы борьбы с вредителями, длительные погодные наблюдения, сформировавшие народный сельскохозяйственный календарь и многое другое. В данном контексте представляется весьма важным изучение опыта сельской общины по сбережению окружающего природного ландшафта.

Таким образом, изучение экологического и социального опыта природопользования, прежде всего крестьянского является весьма актуальным в современных условиях возрастания экологических проблем. Помимо опыта рационального использования местных природных условий хозяйствования этот опыт важен и с общегуманитарной точки зрения, предполагающей высокую экологическую культуру всех членов общества.

\section{Список литературы}

1. Громыко, М. М. Семья и община в традиционной духовной культуре русских крестьян XVIII-XIX вв. // Русские: семейный и общественный быт : [сб. ст.]. - Москва : [б. и.], 1989. - 526 с.

2. Фёдоров, В. М. Биосфера. Земледелие. Человечество. - Москва : Агропромиздат, 1990. 237 с. - (Научно-популярная литература).

3. Миненко, Н. А. Экологические знания и опыт природопользования русских крестьян Сибири XVIII - первая половинаXIX в. - Новосибирск : Наука, 1991. - 210 с. 
4. Ядринцев, Н. М. Поездка по Западной Сибири и в Горный Алтайский округ // Записки Западно-Сибирского Отдела Императорского Русского географического общества. - Омск : [б. и.], 1880. - Кн. $2 . \quad-115$ c. - URL: https://elib.rgo.ru/safe-view/123456789/213949/1/ YWM5YTA2NzgtMTljYy00NzVhLTk1MDItZjk1NjNmYzM5YmNlLjAwMDEucGRm (дата обращения: 01.05.2021).

5. Литературное наследство Сибири : [в 8 т.]. - Новосибирск : Зап.-Сиб. кн. изд-во, 19691988. - Т. 7 : Григорий Николаевич Потанин : Воспоминания (окончание) : Статьи, очерки, рецензии : Воспоминания о Г. Н. Потанине. - 1986. - 339 с., портр.

6. Голубев, П. А. Алтай: историко-статистический сборник по вопросам экономического и гражданского развития Алтайского горного округа. Томск. 1890 // Алтай в трудах учёных и путешественников XVIII - начала XX веков. - Барнаул : А. Р. Т., 2014. - Т. 4. - С. 281-355.

7. Зверев, В. А. Роль семьи в закреплении и передаче опыта хозяйственной деятельности русских крестьян Сибири (конец XIX - начало XX в.) // Земледельческое освоение Сибири в конце XVII - начале XX вв. (Трудовые традиции крестьянства). Новосибирск : Наука, 1985. - С. 112 128.

8. Горьковская, 3. П. Роль трудовых сообществ в формировании традиций промысловой деятельности русских крестьян Сибири в период капитализма // Земледельческое освоение Сибири в конце XVII - начале XX вв. (Трудовые традиции крестьянства). Новосибирск : Наука, 1985. C. $150-159$.

9. Миненко, Н. А. Роль крестьянской общины в организации сельхозпроизводства (по материалам Западной Сибири XVIII - XIX вв.) // Земледельческое освоение Сибири в конце XVII начале XX вв. (Трудовые традиции крестьянства). Новосибирск : Наука, 1985. - С. 40-58.

10. Кузнецов, Д. В. Аграрная реформа П.А. Столыпина и крестьянская община: новый взгляд на старую проблему // Наука о человеке: гуманитарные исследования. - 2014. - № 1. С. $82-92$.

11. Струков, Д. Б. Столыпин. - Москва : Вече, 2012. - 544 с.

12. Щеглова, Т. К. Культура жизнеобеспечения сельского населения юга Западной Сибири в годы Великой Отечественной войны: традиции и новации по материалам полевых исследований 2015-2017 годов // Полевые исследования на Алтае, в Прииртышье и Верхнем Приобье (археология, этнография, устная история): 2017 год : матер. XIII междунар. науч.-практ. конф. (Горно-Алтайск, 24-27 апр. 2018 г.). - Горно-Алтайск : Изд-во Горно-Алт. гос. ун-та, 2018. C. 194-201.

Svetlana I. Bondarenko, Ph. D. in History, Associate Professor Altai State Agrarian University (Russia, Barnaul) bonsvet@bk.ru

\section{SPIRITUAL AND ECOLOGICAL CULTURE OF THE RUSSIAN PEASANT WORLD OF WEST SIBERIA}

Abstract. The paper analyses spiritual, ecological, work experience of historical Russian peasant world of West Siberia (Russia). A role of peasant community, a family in developing of spiritual and ecological traditions of rural community is considered. The author notices a significant of traditional peasant work-related and ecological practices in complicated periods of Russian history. Also, the article debates an importance of basic spiritual and ecological values formed inside peasant community for the current situation.

Keywords: spiritual and ecological culture, peasantry, traditional knowledge, work, family, community, nature, adaptation, nature-saving techniques. 